\title{
Ensaio em dois tempos: revivendo Antígona, a prisioneira
}

\author{
PATRICIA FRANCA-HUCHET
}

Patricia Franca-Huchet é Professora Titular da Escola de Belas Artes da Universidade Federal de Minas Gerais e Pesquisadora do CNPq. Doutora e Mestre pela Université de Paris I | Panthéon/Sorbonne. Graduação pela Université de Paris VIII. Pós-doutorado e residência na Université de Paris III. Trabalha sobre a imagem focalizando seu interesse pela reconstrução crítica da tradição pictural (fotografia, artes plásticas e literatura). Divide as suas atividades artísticas com a prática do ensino, da exposição, da pesquisa, da publicação e do evento: coordenação de eventos e apresentações de trabalho no Brasil e em outros países. Coordena o grupo de pesquisa BE:IT Bureau de estudos sobre a imagem e o tempo. Foi professora pesquisadora da Universidade de São Paulo [ECA-CAP] de 1995 a 1997 a convite de Walter Zanini e Júlio Plaza. Tem obras na coleção da Fondation Danäe, Museu de Lalín França e Espanha -, no Museu de Arte de Brasília, particulares e publicações em livros e revistas no Brasil bem como em outros países. Sua pesquisa Os quatro fotógrafos já foi mostrada em vários países [Paris FR 2009, València ES 2009, Madrid ES 2010, Montreal CA 2011, Florianópolis e Belo Horizonte, BR 2012, Lalín [Bienal] e Porto Alegre 2015. Expõe seus trabalhos no Brasil e em outros países. Foi membro do IAWIS: International Association of word and image studies.

AFILIAÇÃO: Universidade Federal de Minas Gerais (UFMG) Belo Horizonte MG 
- RESUMO

Este ensaio, em um primeiro momento, apresenta uma reflexão sobre um processo artístico envolvendo a personagem de Antígona, da primorosa peça de Sófocles [400 a.C] e, em seguida, montagens de textos e fotografias. Intenta trabalhar o tempo como elemento da narrativa e da montagem literária e visual.

\section{- PALAVRAS-CHAVE}

Fotografia, literatura, história, Antigone. A

\section{- ABSTRACT}

This essay, at a first moment, presents a reflection about an artistic process involving the character of Antigone, taken from Sophocles's exquisite play [400 a.C] and, following that, an assemblage of texts and photographs. The theatricality of photographic images, the literary narrative, and the assemblage were the procedures sought in this work. It aims to deal with "time" as an element for the narrative and the visual and literary assemblage.

KEYWORDS

Photography, literature, story, Antigone. 


\section{Revivendo Antígona}

Tenho, como produtora de imagens, o interesse pela teatralidade, as ficções e cenários. Trabalhando com imagens da história bem como de nossos próprios arquivos, cenarizo ficções constituindo blocos de visualidade sempre inseridos em narrativas. Meu interesse pela abordagem antropológica da fotografia permite o estudo da imagem e, consequentemente, da fotografia de um modo aberto, não sendo sujeito a uma disciplina específica. Neste caso, quando olhamos para uma fotografia é como ver a cena de um teatro: nós olhamos o olhar de alguém sobre o mundo e não o mundo em si. Como uma cena, ou um 'ato'. Aí encontramos também o lugar do espectador.

Retrabalhei a história de Antígona para "remontar" uma história que contemplasse questões que me inquietam. A história de Antígona, pela força de sua persistência no tempo, me levou a criar uma montagem de historicidade e daquilo que costumo pensar que seja arte.

Uma das questões que me preenche na relação entre a literatura e a fotografia se coloca fundamentalmente como imagem. Não se trata apenas de uma absorção de imagens, mas de seu acontecimento no pensar, no sentir e no querer. Em uma civilização como a nossa, na qual a imagem partilha tantas esferas, como por exemplo, a mentira - o simulacro - ela se dá como objeto que consagra nossas estruturas imanentes e nossas formas de lidar com o saber e com o poder. Constitui-se em uma forma de experiência do mundo pelo homem, em todos os domínios (pensando aqui em uma futura mãe que vê a forma de seu bêbê em um ultra-som) mas, especialmente, no que me interessa aqui: abordá-la em suas condições de possibilidades para experiências na estreita relação entre a vida e a obra em sua dimensão fértil, para chamar uma palavra interrogativa e crítica. Cada imagem possui sua propria condição, seu próprio regime histórico, constituindo assim um perímetro antropológico.

Tenho interesse em mostrar alguma realidade que encontro disposta e, como, a partir disso, um trabalho envolvendo a imagem e o texto pode nascer e se formar, que poderá se caracterizar como livro, exposição, instalação, texto ou apresentações de trabalho; objetos culturais, de certa forma. Uma pergunta bem simples, mas não tão fácil de responder: como a partir de um certo número de imagens pode nascer uma prática íntima do texto? Observo a partir de qual momento e qual ponto se começa a delinear uma narrativa, a história sendo, aqui, a visão sobre um conjunto de sinais através dos quais podemos fazer 'montagens'. Essa história poderá explorar diversos espaços, como a arte, a política, a ética, a moral, a paixão e a poesia. A experiência é a vontade de criar formas, através das quais a matéria vai poder ser pensada e formulada, como já disse, pela montagem.

Como já mencionado, trabalhei com fotografias que revisitam a personagem Antígona, da peça teatral de Sófocles [400 a.C]. Esta personagem de envergadu- 
ra histórica e universal possui características que ressoam muito na vida psíquica das mulheres hoje em dia. Antígona está diante do poder e diz não, faz escolhas, tenta não se perder nos limites da linguagem e da confusão mental. Sua magistral solidão e sua rebeldia mostram uma luta lenta e incerta na direção de uma subjetividade livre. Por enquanto, a instalação conta com seis momentos: Infância [Antígona, filha mais velha, brincou à beira das águas protegida por Netuno enquanto tinha como tarefa cuidar de seus irmãos]; sua Secreta Solidão [Antígona é artista e também arqueira, conhece as estrelas e as constelações]; Por onde andou [caminhou como mendiga, seguindo seu pai cego, o maior poeta da cidade]; Fúria [seu transe furioso e catártico decorrente da resistência e da difícil luta contra a tirania: ela foi capaz de enfrentar a mentira e a crueldade]; Meditação [hora de encontrar o vazio, que sempre permite-lhe visualizar outros mundos] e A Prisioneira [quando se encontra à espera do fim]. A teatralidade nesse trabalho é para que não nos esqueçamos que esta instalação tem como fundamento uma personagem do teatro, que fascinou dentre inúmeros filósofos, artistas, escritores, poetas, historiadores e pensadores como G. W. Friedrich Hegel, os poetas Friedrich Hölderlin e Johann W. Goethe, Bertold Brecht, Jacques Lacan, Henry Bauchau, Jean Cocteau, Júlia Kristeva, Philippe Lacoue-Labarthe, Jacques Derrida, Judith Butler e, até mesmo Jeanne Moreau, artista francêsa, que em depoimento revela ter sido a peça Antígona - vista por ela aos treze anos - que proporcionou-lhe a percepção do teatro e o desejo intenso de conhecê-lo.

O ensaio fotógrafico que segue - A Prisioneira - é acompanhado de montagens de trechos do esplendoroso livro A montanha mágica de Thomas Mann, com inserções minhas. Substituí o nome do querido Hans Castorp pelo de Antígona e, algumas vezes, fiz uma livre adaptação para que o texto encontrasse com mais facilidade o caminho da figura que aqui vos apresento. Antígona está sempre presente através dos tempos! Oras, para que não nos esqueçamos que o tempo é sempre revolto e que podemos, sem sombra de dúvida, sentirmo-nos arrebatados para o "lá e o outrora" 


\section{A PRISIONEIRA}

Esta história já se passou há muito tempo, está recoberta, por assim dizer, pela patina do tempo e deve ser relatada, incondicionalmente, na forma do passado mais remoto. Isso talvez não seja desvantagem para história alguma, mas vantagem; é necessário que as histórias já tenham passado, caberia dizer, melhor corresponderão à sua qualidade esssencial de histórias, e mais adequadas serão ao narrador, esse mago que evoca o pretérito. Acontece porém com a história o que hoje acontece com os homens, e entre eles, não em ultimo lugar, com os narradores de histórias: ela é muito mais velha que seus anos; sua vetustez não pode ser medida por dias, nem o tempo que sobre ela pesa, por revoluções em torno do sol. Numa palavra, não é propriamente ao tempo que a história deve o seu grau de antiguidade - e o que se pretende com essa observação feita de passagem é aludir e remeter ao caráter problemático e à peculiar duplicidade desse elemento misterioso.

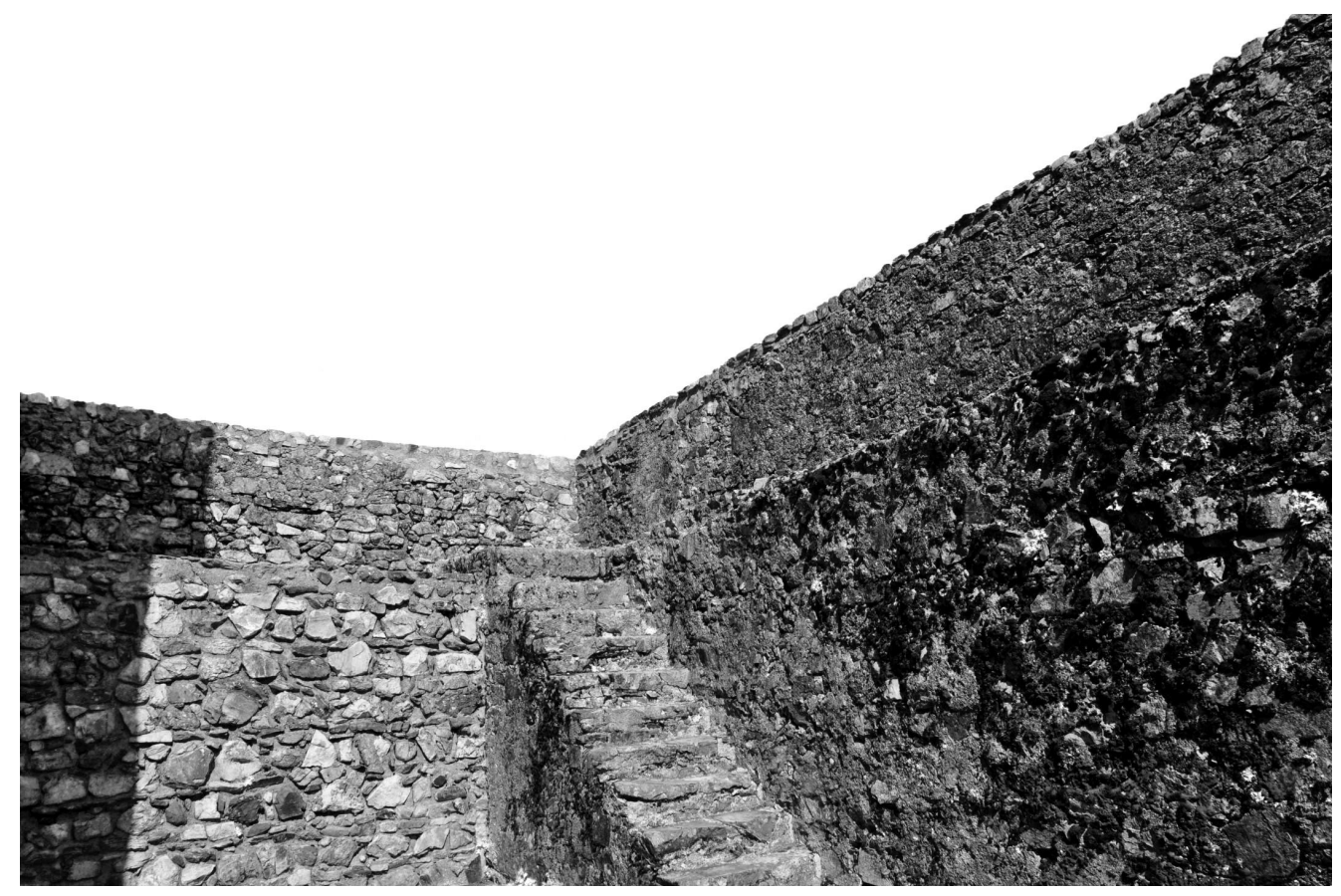


Ora, isso poderia causar espanto; e todavia está bem assim, corresponde às leis do narrar e do ouvir; corresponde às ditas leis que o tempo se torne para nós tão longo ou tão curto que ele se afigure tão vasto ou tão reduzido à nossa experiência quanto o é para Antígona, a heroína de nossa história, requisitada pelo destino de modos tão inesperados. $E$, em vista do mistério que constitui o tempo, pode ser proveitoso preparar o espectador para outros milagres e fenômenos com que deparamos em companhia de Antígona.

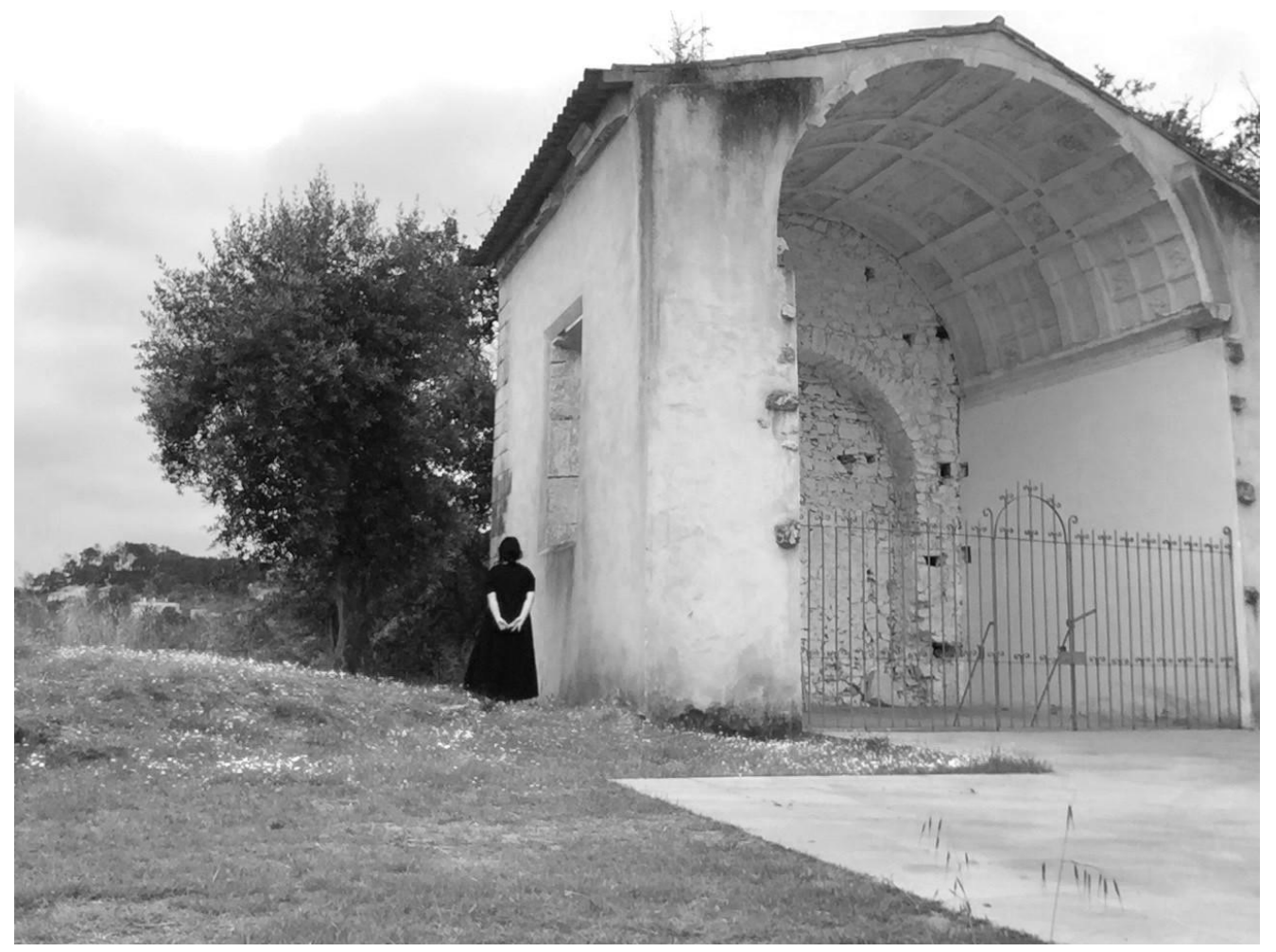


A manhã estava fresca e nublada. Vastas massas de neblina jaziam imóveis diante das elevações laterais, enquanto volumosas nuvens brancas e cinzentas repousavam sobre os topos das árvores mais distantes. Pedaços e tiras de céu azul apareciam aqui e ali, e quando um raio de sol caía sobre o fundo do vale a aldeia cintilava muito alva, contrastando com os olivais sombrios que cobriam as encostas. Em algum lugar se dava um concerto matinal, provavelmente no mesmo templo de onde viera, na noite anterior, o som de um coral de vozes infantis. Ouvia-se na surdina os acordes de um hino religioso; depois de uma pausa, seguiu-se um canto suave e feminino, e Antígona, que gostava de música de todo o coração, sentiu produzir nela um efeito calmante, entorpecente, escutou-a satisfeita, com a cabeça levemente inclinada para o lado, a boca aberta e os olhos um pouco avermelhados.

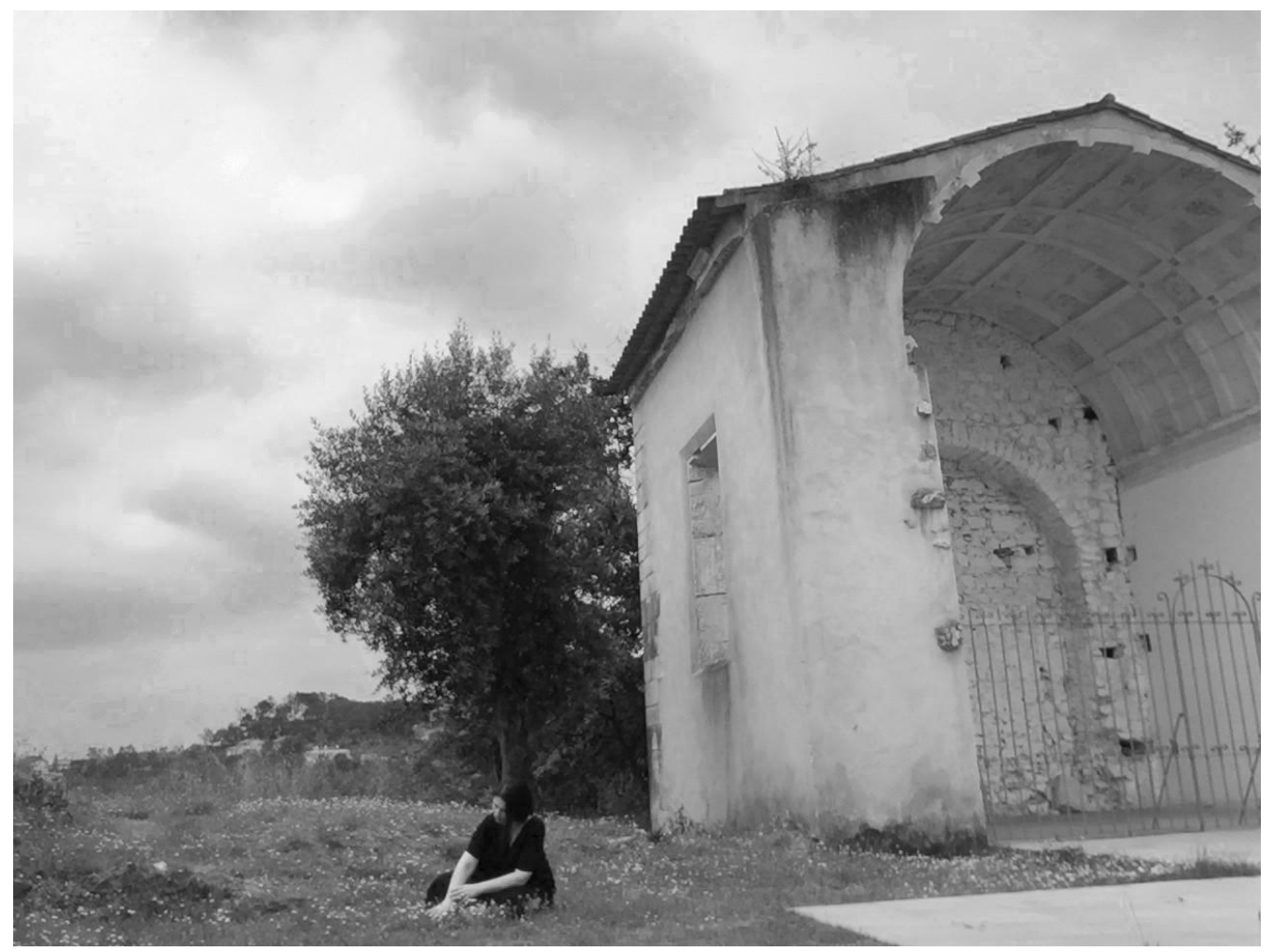

ouvirouver Uberlândia v. 14 n. 2 p. $422-436$ jul. |dez. 2018 
Eis que, de súbito, sentiu-se transportada para aquela fase remota de sua vida, em que passara a cena original de um sonho remodelado em conformidade com impressões mais recentes, e que tivera poucas noites atrás...Viu-se arrebatada para o lá e o outrora, sem deixar qualquer vestígio, a ponto de suspender o espaço e o tempo, e com tanto vigor que se poderia dizer que nas pedras junto ao seu esconderijo jazia um corpo inânime, ao passo que a verdadeira Antígona se encontrava longe dali, num ambiente e numa época muito distantes - e ainda numa situação que, apesar da sua simplicidade, era para ela arriscada e lhe inebriava o coração. Perto da morte, meditando sobre a singularidade da sua situação, às vezes, um riso louco de triunfo subia-lhe do fundo da alma e the sacudia o peito, enquanto seu coração estacava, dolorido, sob o efeito de uma desmedida e até então ignorada alegria e esperança; outras vezes, porém, empalidecia de susto e desassossego, e eram goles da sua propria consciência que o coração repetia, numa cadência acelerada, errática, batendo-lhe nas costelas.

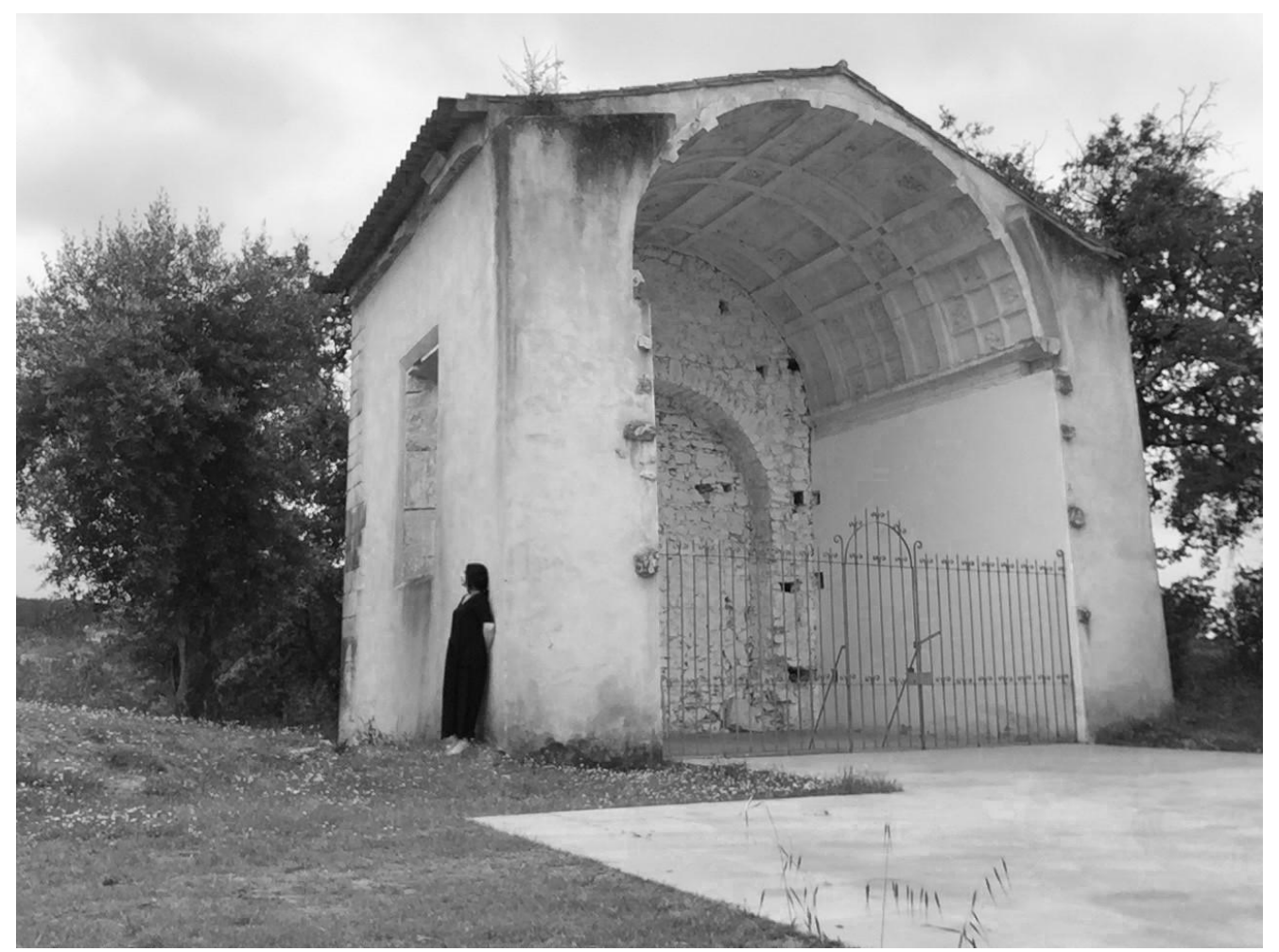


Fora perto das sete horas; o sol já se pusera e a lua quase cheia já se elevara, a leste, por cima das margens do lago, cobertas de arbustos. E durante dez minutos, enquanto Antígona rabiscava a terra com gravetos e pedrinhas, reinava uma constelação perturbadora, fantástica qual um sonho. A oeste resplandera, como em pleno dia, uma luz vítrea, prosaica, decidida; mas bastava voltar a cabeça para deparar com uma paisagem de luar, igualmente típica, entremeada de brumas úmidas e de mágico encanto. Esse contraste esquisito durara um quarto de hora, pouco mais ou menos, antes de se completar o triunfo da noite e da lua. Com um pasmo alegre, os olhos deslumbrados e confundidos de Antígona haviam passado de uma iluminação e de uma paisagem à outra, do dia para a noite e da noite para o dia. E nesse instante, vislumbrou a história do pai e da mãe.

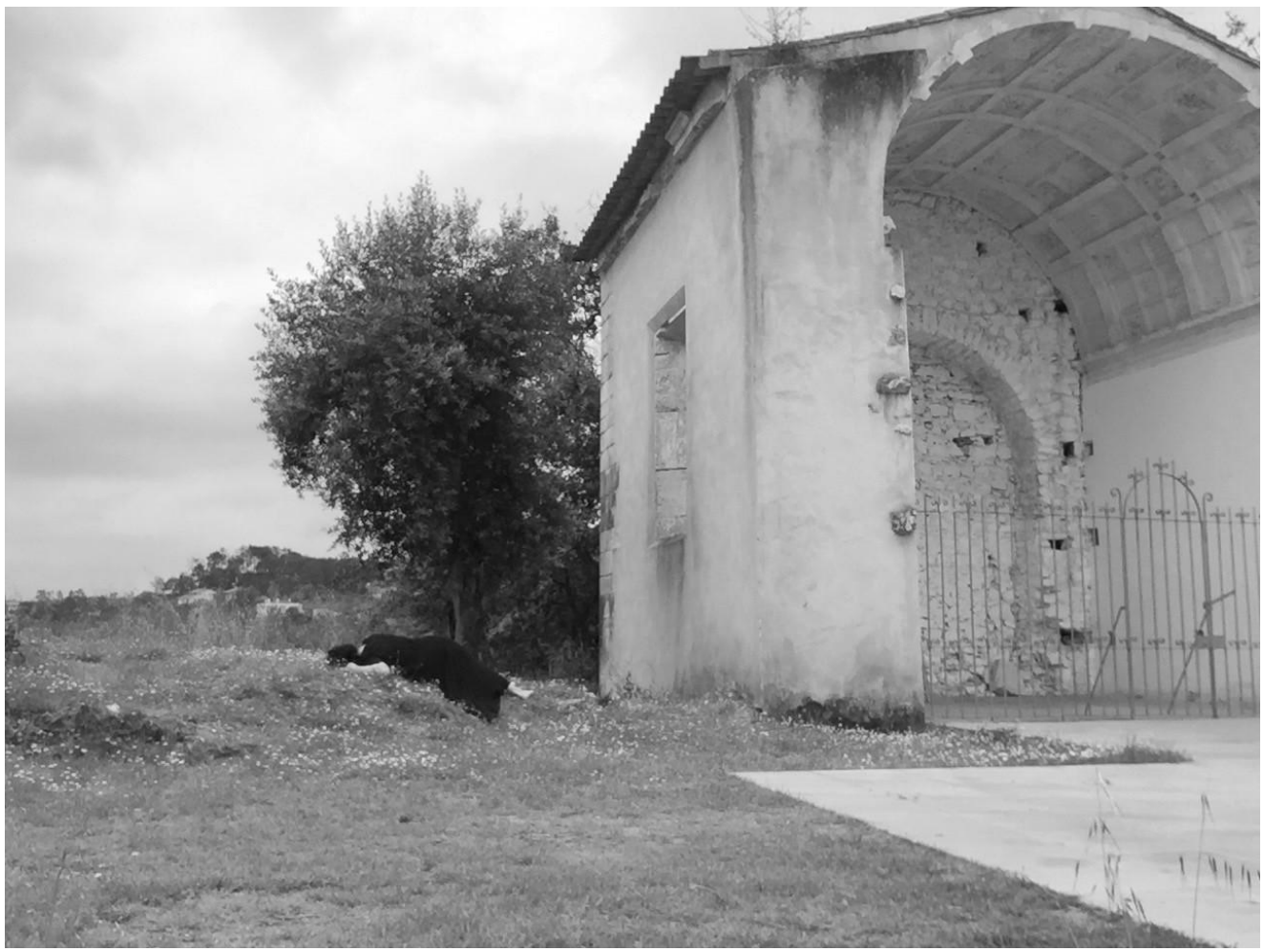

ouvirouver U Uberlândia v. 14 n. 2 p. $422-436$ jul. |dez. 2018 
À noite, Antígona contemplava os astros. Apossara-se dela o interesse pelo transcurso do ano, posto que já estivesse assistido na terra a mais de vinte voltas em torno do sol. - Sim senhor, o zodíaco, o círculo dos signos. As velhíssimas constelações: Escorpião, Sagitário, Capricórnio etc. Não é possível não se interessar por isso. Há doze signos, como você deve saber. Três para cada estação, os ascendentes e os descendentes, a órbita das constelações que o sol perfaz. Ela achou isso grandioso! Imagine que os encontraram pintados no teto de um templo egípcio; era até um templo de Afrodite, nas proximidades de Tebas. Os caldeus também os conheciam; os caldeus, sabe? Aquele velho povo de magos, de origem árabe e semítica, sumamente versado em astrologia e profecias. Também eles já estudaram o cinturião celeste, por onde se movimentam os planetas, e subdividiram-no nesses doze signos, os dodecatemoria, tais como foram transmitidos. É notável! Isso é a humanidade!

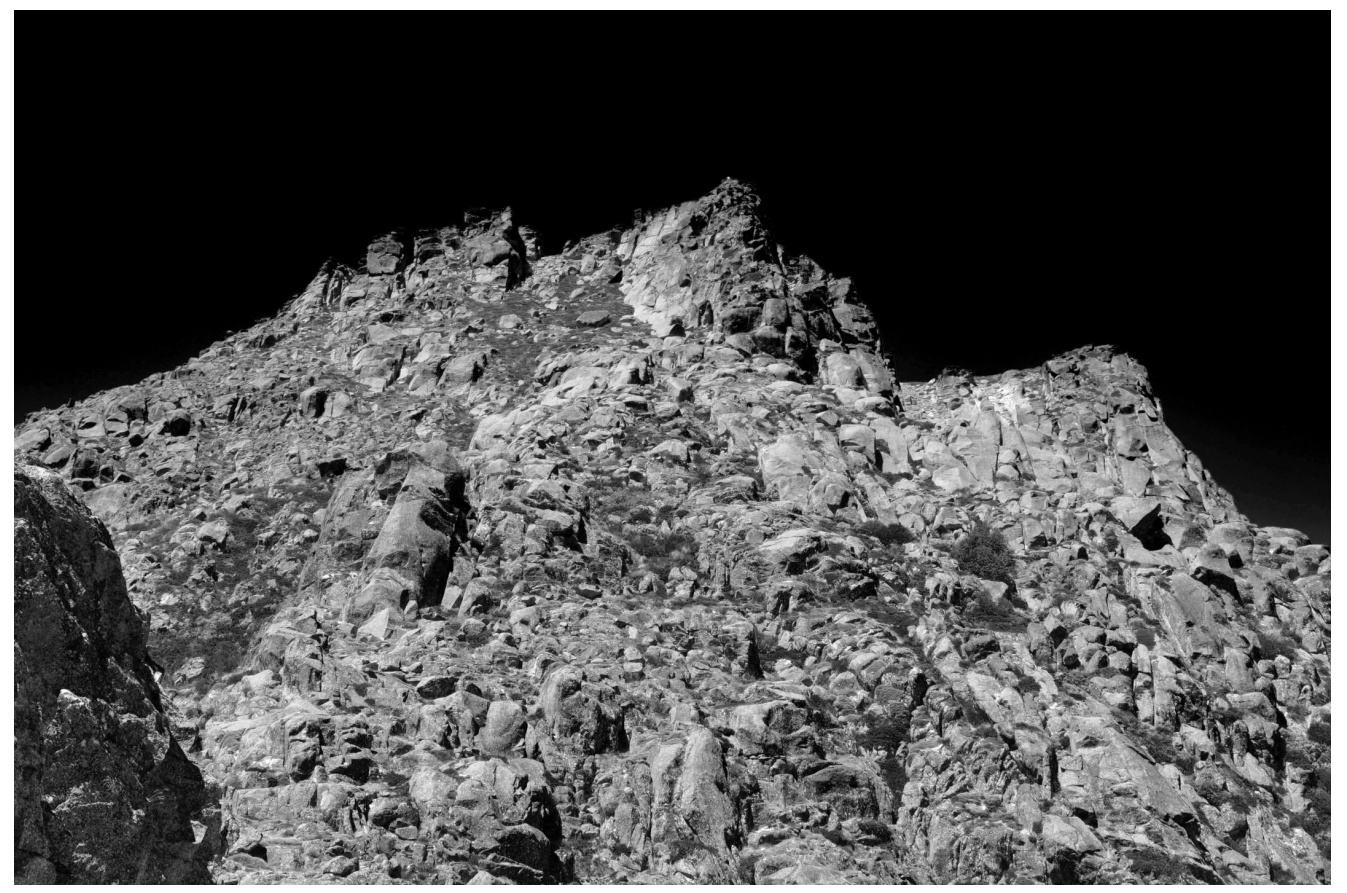


Escutava de seu retiro os festejos de solstício. Solstício de verão! Fogueiras acesas nas montanhas e cirandas dançadas de mãos dadas ao redor das labaredas erguidas. Assim faziam os homens primitivos, quando celebravam a primeira noite de verão, essa hora meridiana e esse ponto culminante do ano, donde, então parte a descida. Dançam, giram e exultam. Agem assim por puro desepero, se me permite essa expressão, em homenagem ao círculo falaz e à eternidade sem rumo duradouro, no qual tudo se repete. Ah, sim! É isso! - exclamou nela uma voz, como se desde tempos imemoriais tivesse levado no seu coração, às escondidas e sem confessá-lo a si própria, toda essa alegria azul, irradiada pelo sol. E "esses tempos imemoriais" eram vastos, infinitamente vastos, tal e qual o mar que se abria à sua esquerda, ali onde o céu, num tom delicado de violeta, descia até as águas. O coração de Antígona se abriu dolorosamente, por inteiro, amando o que via diante de si.

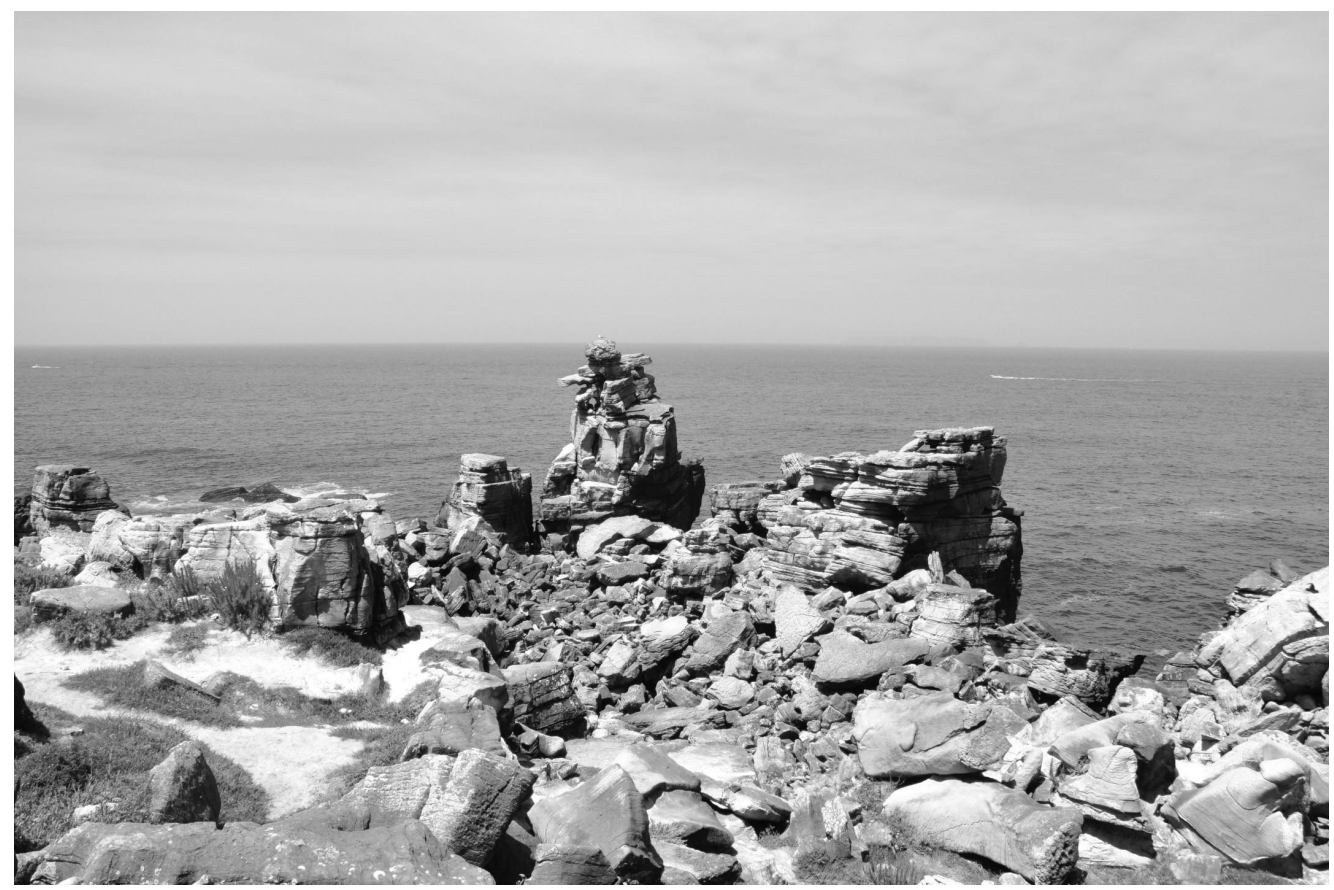

ouvirouver Uberlândia v. 14 n. 2 p. $422-436$ jul. |dez. 2018 
Ela ainda sabia muito bem o quanto, em diversos daqueles sonhos excessivamente agitados que naqueles dias the encheram as noites, exasperava-se por causa das guerras em torno de si. As flechas que enviava na direção se seus oponentes não acertavam o alvo voluntariamente, apenas raspavam de leve a pele daqueles soldados inocentes. Mas isso se passara num sonho, e Antígona acordada era diferente, menos livre de inibições quando sonhava. Em estado de vigília tudo pode ser de outro modo; talvez fizesse bem tentando conformar-se intimamente com essa maneira de ser, completamente nova para ela. Quem sabia se não eram dignas de ser estudadas sua rebeldia e sua crítica? Sou tentada a dizer que não extraímos os sonhos unicamente da nossa propria alma. Sonhamos anônima e coletivamente, embora de forma individual. A grande alma, da qual você é apenas uma partícula, talvez sonhe por meio de você. Cabe- me, é o que afirmo, tenho o genuíno direito de deitar-me aqui e de me entregar a esse tipo de sonhos... O que sonhara já estava em vias de apagar. E o que pensara, naquela mesma noite já não entendia muito bem.

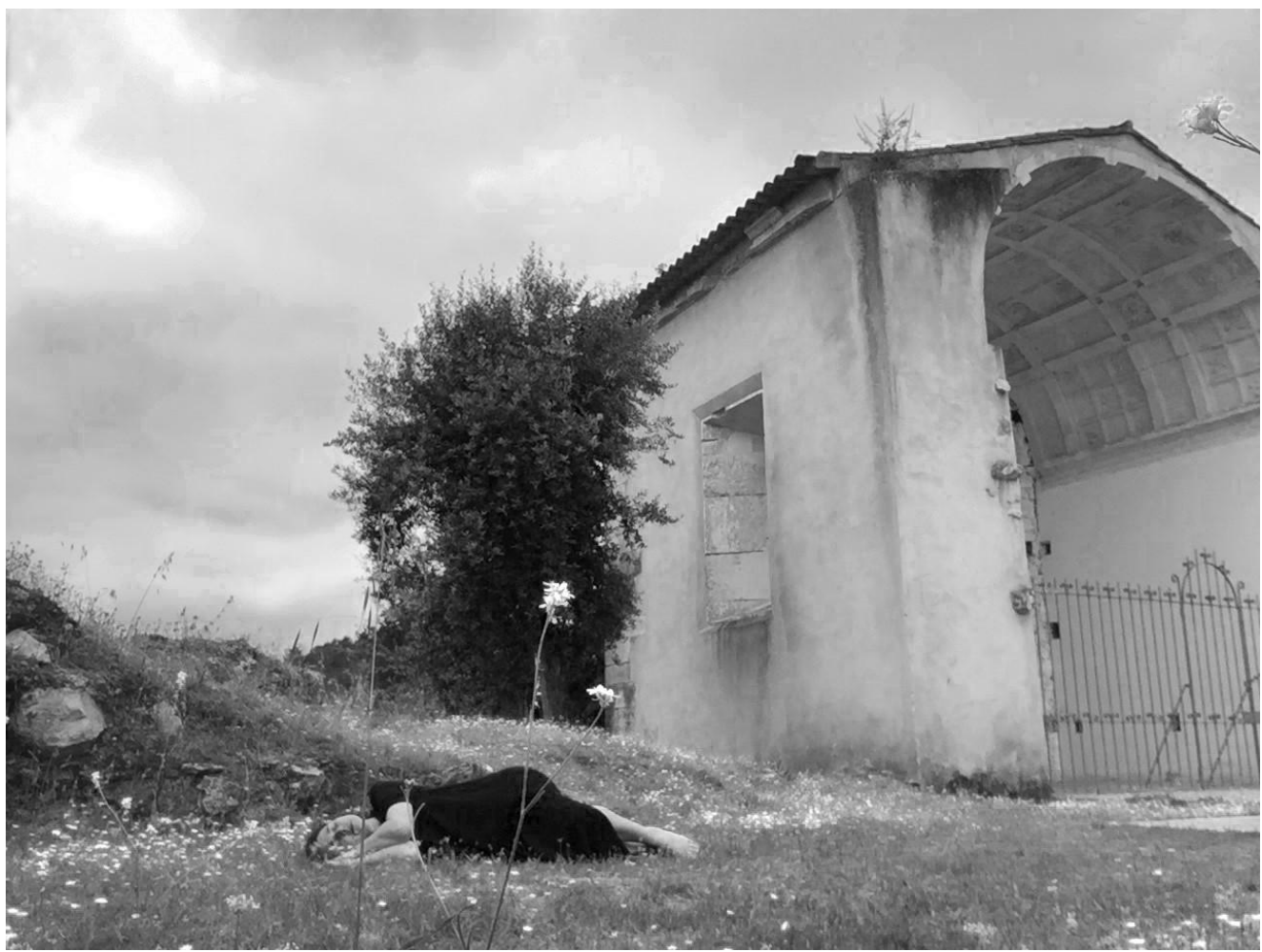


O enfermo é justamente um enfermo, tem uma natureza particular e o modo de sentir alterado, como decorrência de seu estado; a doença prepara o sujeito de modo que os dois, ela e ele, se entendam bem: há diminuições de sensibilidade, desfalecimentos, narcosis providenciais, medidas da natureza, no sentido do ajustamento e alívio morais espirituais, fenômenos que o homem sadio, na sua ingenuidade, se esquece de levar em conta.

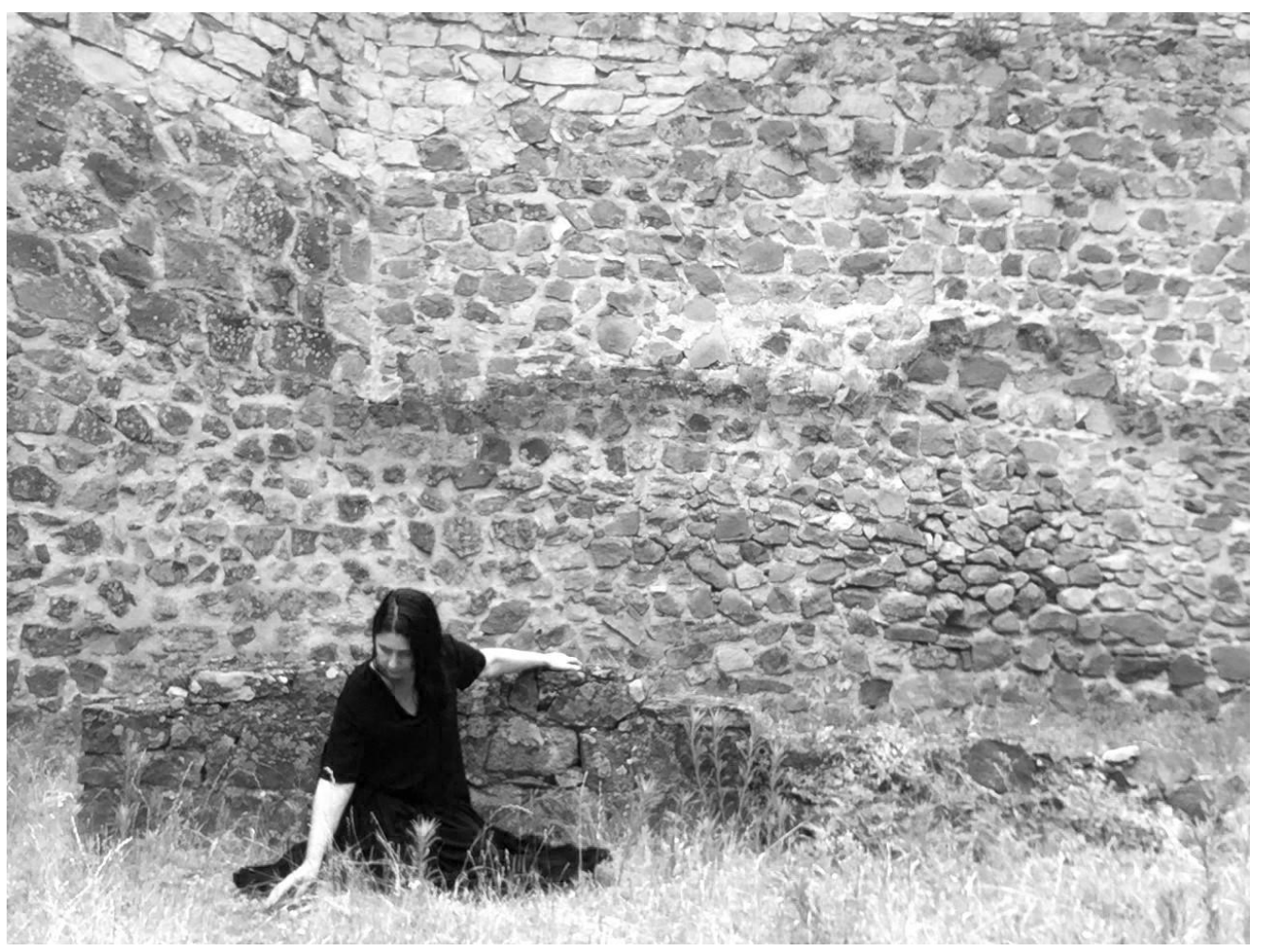


O tempo é o elemento da narrativa, assim como é o elemento da vida: está ligado à ela como aos corpos no espaço. E se lançamos a questão sobre a possibilidade de narrar o tempo, foi só para confessar que, com a presente história e sob tais condições, nada nos resguardaria de mergulharmos na mais profunda ignorância quanto ao curso do tempo, e de perdermos, por conseguinte, a noção da nossa idade. Esse fenômeno é possível, já que não temos em nossas entranhas, em absoluto, um orgão para o tempo, o que nos torna incapazes de avaliar, nem sequer por aproximação, o decurso do tempo a partir de nós mesmos e sem basear-nos em indícios exteriores.

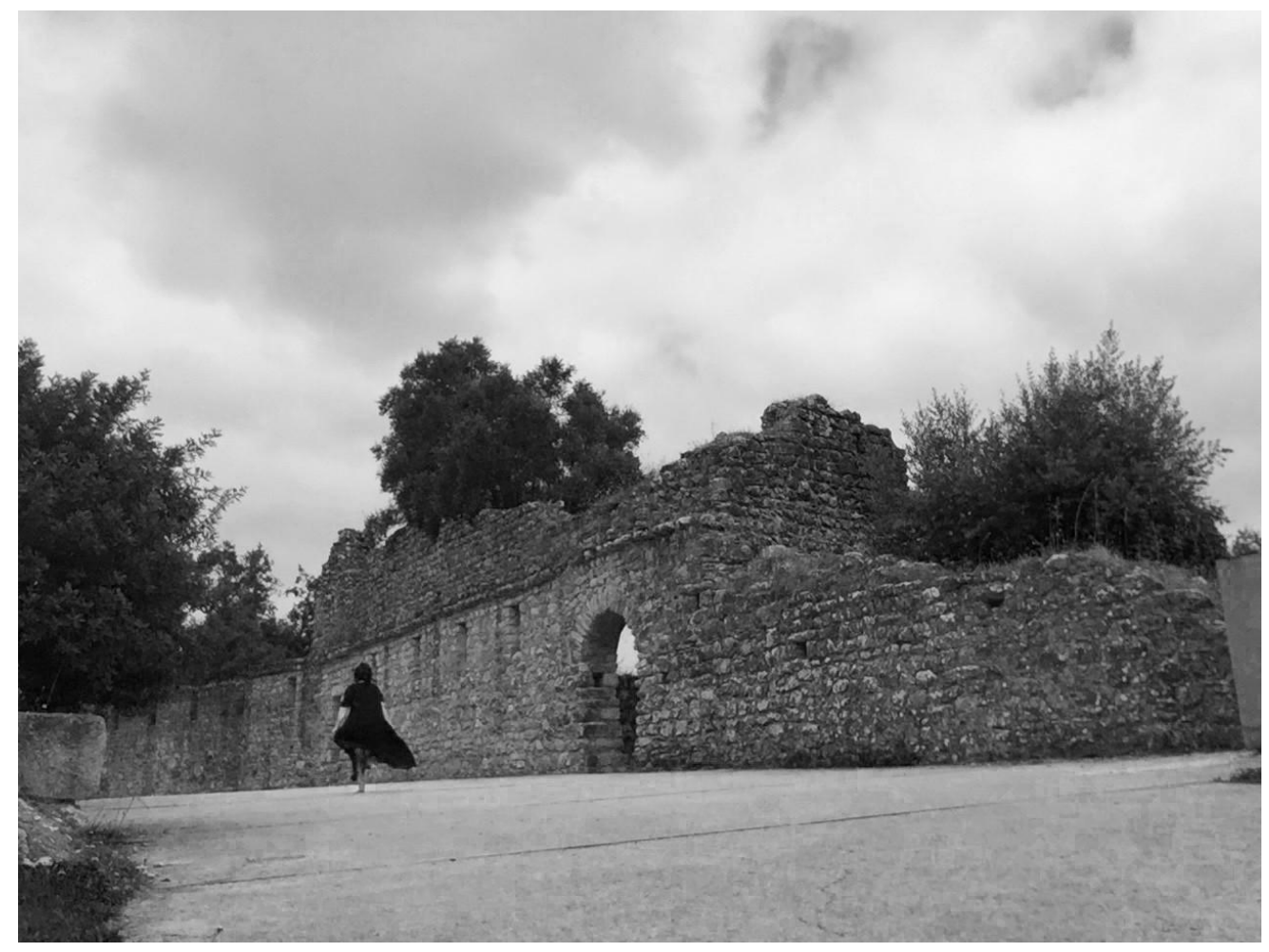


Como citar:

FRANCA-HUCHET, Patricia . Ensaio em dois tempos: revivendo Antígona, a prisioneira. ouvirOUver; Uberlândia, v.14,n.2, p.422-436, jul./dez. 2018. Disponível em: http://www.seer.ufu.br/index.php/ouvirouver; DOI:http://doi.org/10.14393/OUV23v14n2a2018-12 